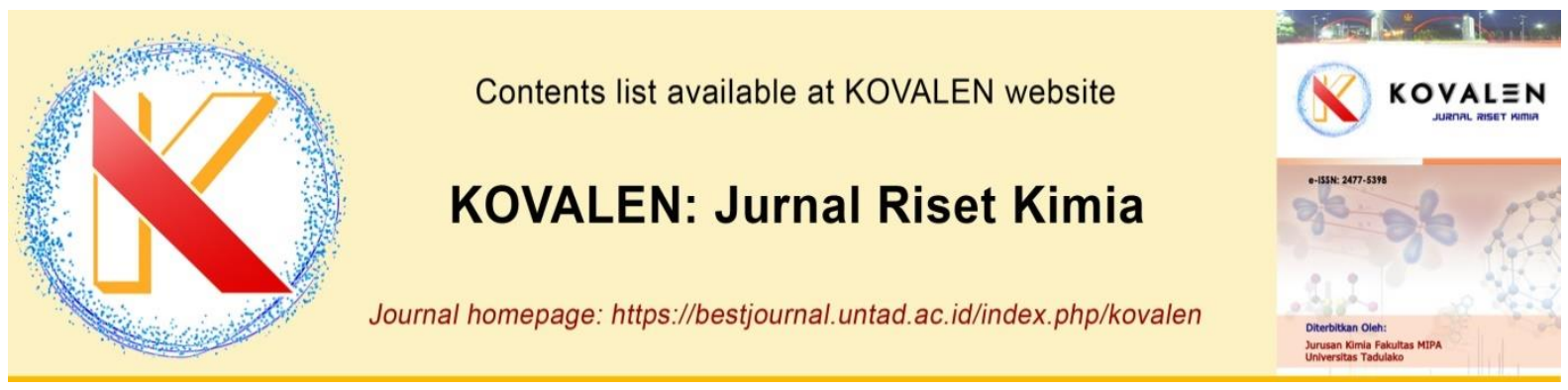

\title{
Analisis Kadar Glukomanan Dari Biji Durian (Durio zeibethinus Murr) dengan Metode Spektrofotometri pada Berbagai Waktu dan Suhu Hidrolisis
}

\section{[Analysis of Glucomannan Content From Durian Seeds (Durio zeibethinus Murr) Using Spectrophotometry Methods in Several Hydrolysis Times and Temperatures]}

\author{
Darmawati , Syaiful Bahri, Husain Sosidi \\ Jurusan Kimia Fakultas Matematika dan IImu Pengetahuan Alam Universitas Tadulako \\ Jl. Soekarno-Hatta Km. 9, Kampus Bumi Tadulako, Palu, Indonesia \\ ${ }^{\star}$ Coresponding Author. ammadamma0808013@gmail.com
}

\begin{abstract}
Durian seeds are one type of seed that contains glucomannan. The aim is to determine glucomannan levels in the durian seed. The study was designed using a completely randomized design (CRD). The extracted glucomannan was determined by the spectrophotometry method at various temperature and hydrolysis time. The crude extract of glucomannan was hydrolyzed using $3 \mathrm{M} \mathrm{HCl}$ for $70,80,90,100$, and 110 minutes at $70,80,90,100$, and $110^{\circ} \mathrm{C}$. The highest glucomannan concentration of $39.60 \%$ was obtained at a hydrolysis temperature of $100^{\circ} \mathrm{C}$ for 100 minutes. The analysis of the FTIR spectrophotometer shown that the vibration of the C-O-C functional group (glycoside bond) was obtained at the wavelength number of $1020.34 \mathrm{~cm}^{-1}$ which is a characteristic of glucomannan.
\end{abstract}

Keywords: glucomannan, durian seed, hydrolysis, spectrophotometry

ABSTRAK. Biji durian adalah salah satu jenis biji yang mengandung glukomanan. Tujuan penelitian ini adalah untuk menentukan kadar glukomanan pada biji durian. Penelitian ini dilakukan menggunakan Rancangan Acak Lengkap (RAL). Glukomanan hasil ekstraksi ditentukan kadarnya dengan metode spektrofotometri pada berbagai variasi waktu dan suhu hidrolisis. Ekstrak kasar glukomanan dihidrolisis dengan $\mathrm{HCl} 3 \mathrm{M}$ selama selama 70, 80, 90,100 , dan 110 menit pada suhu $70,80,90,100$, dan $110^{\circ} \mathrm{C}$. Kadar glukomanan tertinggi diperoleh pada waktu hidrolisis 100 menit pada suhu hidrolisis $100^{\circ} \mathrm{C}$ yaitu $39,60 \%$. Hasil analisis spektrofotometer FTIR menunjukkan bahwa terdapat pita serapan gugus fungsi C-O-C (ikatan glikosidik) pada bilangan gelombang $1020,34 \mathrm{~cm}^{-1}$ yang merupakan ciri khas dari glukomanan.

Kata Kunci: glukomanan, biji durian, hidrolisis, spektrofotometri 


\section{LATAR BELAKANG}

Durian merupakan salah satu buah yang sangat populer di Indonesia. Menurut Kementan (2016), produki durian di Indonesia pada tahun 2014 mencapai 857,118 ton dan pada tahun 2015 meningkat menjadi 995,729 ton. Peningkatan produksi ini disebabkan oleh meningkatnya luas daerah panen durian yaitu 67,779 ha pada tahun 2014 menjadi 82,321 ha pada tahun 2015.

Bagian durian yang dikonsumsi adalah daging buah dengan persentase 20-35\%, bagian kulit $60-75 \%$ dan biji durian 5-15\% (Wahyono, 2009). Biji durian mengandung komponen seperti protein, lemak, kalsium, serat, fosfor, karbohidrat dan polisakarida larut air (PLA) (Aida \& Laelia, 2011). Andini (2014) melaporkan bahwa rendemen PLA dari biji durian mencapai 4,28\%. PLA merupakan polisakarida non pati yang dapat larut air seperti pektin dan gum (galaktan, glukomanan, galaktomanan dan xilan). Prabowo et al. (2014) melaporkan bahwa PLA umumnya mengandung polisakarida utama berupa glukomanan. Merujuk dari data tersebut maka biji durian memiliki potensi sebagai salah satu sumber penghasil glukomanan selain umbi porang.

Pemanfaatan glukomanan sangat banyak dalam berbagai bidang industri seperti untuk mengurangi respon glukemik, menurunkan kolesterol (Singh \& Shelley, 2007), sebagai pengenyal dan pengental pengganti boraks (Hargono, 2008) dan sebagai perekat pada industri tekstil (Chairul \& Sofnie, 2006).

Beberapa penelitian tentang produksi glukomanan juga telah dilakukan dari berbagai jenis tanaman namun dengan menggunakan metode gravimetri seperti umbi iles-iles dengan rendemen 42,35-80,53\% (Nurjannah, 2010), dari umbi porang dengan kadar glukomanan berkisar antara 50-60\% (Fatmawati et al., 2017) dan dari lidah buaya (Retnowati \& Kumoro, 2012). Glukomanan dari biji-bijian yang telah diteliti sebelumnya yaitu dari tepung biji salak dengan rendemen sebesar 40,19\% (Anindita et al., 2016).

Rendemen glukomanan yang diperoleh dari beberapa tanaman yang telah disebutkan sebelumnya, dipengaruhi oleh suhu ekstraksi (Setiawati et al., 2017), waktu ekstraksi, perbandingan pelarut dan massa padatan (Fadilah et al., 2009), varietas, metode ekstraksi, jenis antisolven (Retnowati \& Kumoro, 2012), rasio massa padatan terhadap antisolvent (Anindita et al., 2016). Penentuan kadar glukomanan dapat dilakukan dengan dua metode, yaitu metode gravimetri dan metode spektrofotometri. Metode gravimetri adalah suatu analisis kuantitatif yang didasarkanpada pengukuran berat endapan yang diperoleh dari proses pemisahan komponen zat tertentu. Analisis kadar glukomanan dengan metode spektrofotometri telah dilakukan oleh beberapa peneliti sebelumnya, tetapi penelitian-penelitian tersebut umumnya dilakukan pada suhu dan waktu hidrolisis yang sama, yaitu selama 90 menit pada suhu $100^{\circ} \mathrm{C}$ (Mustafa \& Widjanarko, 2015), sehingga diperlukan kajian variasi waktu dan suhu hidrolisis untuk menguji ketelitian metode spektrofotometri.

\section{METODE PENELITIAN}

\section{Bahan dan Peralatan}

Bahan utama yang digunakan dalam penelitian adalah biji durian, akuades, etanol $95 \%, \mathrm{NaOH} 0,5 \%$ dan $10 \%, \mathrm{NaOH} 6 \mathrm{M}$, asam formiat (Merck), asam asetat (Merck), etanol $95 \%$, fenol, natrium kalium tartrat (Merck), $\mathrm{HCl}$ 3M, 3,5-DNS, natrium bisulfit (Merck) dan isopropil alkohol (Merck). 
Peralatan yang digunakan dalam penelitian ini adalah blender, pipet ukur $2 \mathrm{~mL}, 5 \mathrm{~mL}$ dan 10 $\mathrm{mL}$, hot plate (Wise Stir MSH 20-D), karet pengisap, magnetic stirrer (Faithfull sh-2), spetrofotometer UV-VIS (PerkinElmer L850), centrifuge, neraca analitik (Adventurer ohaus), desikator, lemari asam, penangas air (Memmert), ayakan 60 mesh, gegep dan alatalat gelas lainnya.

\section{Prosedur Penelitian}

\section{Pembuatan tepung glukomanan (Syaefullah, 1990)}

Biji durian dicuci dengan air mengalir hingga bersih kemudian dipisahkan antara kulit dan dagingnya. Setelah itu biji diiris tipis-tipis dan dikeringkan dibawah sinar matahari. Biji durian kering diblender dan diayak dengan ayakan 60 mesh hingga diperoleh tepung biji durian. 10 gram tepung biji durian dicampurkan sedikit demi sedikit ke dalam akuades dengan perbandingan 1:30 (b/v) sambil diaduk menggunakan homogenizer pada kecepatan $700 \mathrm{rpm}$ dan pemanasan suhu $95^{\circ} \mathrm{C}$ selama 120 menit. Campuran didinginkan dan disentrifugasi dengan kecepatan 3000 rpm selama 15 menit. Filtrat dipekatkan hingga setengah volume awal lalu ditambahkan anti-solvent isopropil alkohol 95\% dengan perbandingan 1:19 (b/v) untuk mengendapkan glukomanan. Glukomanan dicuci dengan etanol 95\% dan dikeringkan untuk memperoleh tepung glukomanan. Tepung glukomanan dianalisa dengan spektrofotometer FT-IR.

\section{Pengaruh waktu dan suhu hidrolisis terhadap kadar glukomanan dari tepung biji durian (Widjanarko \& Megawati, 2015)}

Tahapan ini menggunakan rancangan acak lengkap bertingkat. Glukomanan biji durian ditimbang $1 \mathrm{~g}$ lalu ditambahkan $50 \mathrm{~mL}$ buffer asam formiat- $\mathrm{NaOH}$ dan diagitasi dengan magnetic stirrer pada suhu ruang selama 4 jam. Campuran diencerkan hingga $100 \mathrm{~mL}$ dengan buffer. Campuran disentrifugasi $4000 \mathrm{rpm}$ selama 20 menit untuk diambil supernatannya. Supernatan dihidrolisis menggunakan asam klorida 3 M pada suhu 70, 80, 90, 100, dan $110^{\circ} \mathrm{C}$ dengan variasi waktu $70,80,90,100$ dan 110 menit. Hasil hidrolisis didinginkan pada suhu ruang dan ditambahkan $\mathrm{NaOH} 6 \mathrm{M}$, lalu diencerkan dengan akuades hingga $25 \mathrm{~mL}$. Hasil yang didapatkan merupakan hidrolisat glukomanan. Supernatan, hidrolisat glukomanan, dan buffer (blanko) masing-masing $1 \mathrm{~mL}$ ditambahakan $3 \mathrm{~mL}$ reagen 3,5-DNS kemudian dipanaskan dalam penangas air selama 5 menit. Larutan didinginkan hingga suhu ruang lalu diencerkan dengan akuades hingga $25 \mathrm{~mL}$. Masing-masing diukur absorbansinya dengan spektrofotometer UV-VIS pada panjang gelombang $550 \mathrm{~nm}$. Kandungan glukosa pada larutan sampel dan hidrolisat ditentukan dengan memasukkan nilai absorbansi pada persamaan garis lurus regresi kurva standar glukosa. Kadar glukomanan dapat dihutung dengan persamaan:

$$
\text { (\%)glukomanan }=\frac{f(5 T-T o) \times 50}{m} \times 100
$$

Keterangan:

$\mathrm{f}=$ faktor koreksi (Rasio BM glukosa dan residu mannan dengan BM glukosa dan mannan yang dihasilkan setelah hidrolisis)

$\mathrm{T}$ = Jumlah (mg) glukosa dalam glukomanan hidrolisat yang diperoleh dari kurva standar

To = Jumlah (mg) glukosa dalam supernatan glukomanan yang diperoleh dari kurva standar

$\mathrm{m}$ = massa sampel $(1000 \mathrm{mg})$

\section{HASIL DAN PEMBAHASAN}

\section{Hasil Analisis FT-IR Ekstrak Glukomanan Biji Durian}

Serapan vibrasi ulur gugus - $\mathrm{OH}$ terdapat pada bilangan gelombang $3425,58 \mathrm{~cm}^{-1}$ (Tabel 
1). Widjanarko et al., (2011) mengatakan bahwa serapan vibrasi ulur $-\mathrm{OH}$ terletak pada spektrum $3391,59 \mathrm{~cm}^{-1}$. Serapan pada bilangan gelombang 2926,01 $\mathrm{cm}^{-1}$ menunjukkan vibrasi ulur gugus $\mathrm{C}-\mathrm{H}$ alkana $\left(-\mathrm{CH},-\mathrm{CH}_{3}\right.$ atau $\left.-\mathrm{CH}_{2}^{-}\right)$ (Tabel 1). Menurut Chao-bo et al., (1999), puncak serapan gugus metil glukomanan berada pada panjang gelombang $2920 \mathrm{~cm}^{-1}$. Pita serapan pada bilangan gelombang 1653,00 $\mathrm{cm}^{-1}$ menunjukkan adanya gugus $\mathrm{C}=\mathrm{O}$ (Tabel 1). Pada penelitian Nguyen et al. (2010), pita serapan gugus $\mathrm{C}=\mathrm{O}$ berada pada bilangan gelombang $1726 \mathrm{~cm}^{-1}$. Chao-bo et al., (1999) menyatakan bahwa puncak serapan spektrum pada gugus karbonil glukomanan yang ditambahkan akrilamida terletak di daerah 1671 $\mathrm{cm}^{-1}$.

Pita serapan pada daerah bilangan gelombang 1020,34 $\mathrm{cm}^{-1}$ menunjukkan adanya gugus fungsi C-O-C (ikatan glikosidik) (Tabel 1). Widjanarko et al., (2011) menyatakan bahwa gugus fungsi $\mathrm{C}-\mathrm{O}-\mathrm{C}$ berada pada bilangan gelombang $1027,02 \mathrm{~cm}^{-1}$. Pita serapan pada panjang gelombang $850,61 \mathrm{~cm}^{-1}$ menunjukkan adanya serapan vibrasi tekuk - $\mathrm{CH}$ (Tabel 1). Menurut Yf et al. (2004), gugus glukosa dan mannose terlihat pada panjang gelombang 814 dan $873 \mathrm{~cm}^{-1}$ yang berhubungan dengan vibrasi tekukan gugus $-\mathrm{CH}$.

Tabel 1. Perbandingan bilangan gelombang glukomanan hasil penelitian dengan referensi.

\begin{tabular}{cccc}
\hline & & \multicolumn{2}{c}{ Bilangan gelombang glukomanan $\left(\mathrm{cm}^{-1}\right)$} \\
\cline { 3 - 4 } No & Gugus fungsi & Hasil penelitian biji durian & $\begin{array}{c}\text { umbi porang } \\
\text { (Widjanarko et al., 2011)) }\end{array}$ \\
\hline 1 & O-H ulur & 3425,58 & 3391,59 \\
2 & - C-H alkane & 2926,01 & 2901,7 \\
3 & C=O ulur & 1653,00 & 1636,49 \\
4 & C-O-C ulur & 1020,34 & 1027,02 \\
5 & C-H tekuk & 850,61 & 875,62 \\
\hline
\end{tabular}

Kadar Glukomanan Biji Durian pada Berbagai Waktu Hidrolisis

Kadar glukomanan dalam penelitian ini ditentukan dengan menggunakan metode spektrofotometri, karena menurut Widjanarko \& Megawati (2015) metode spektrofotometri menunjukkan akurasi yang lebih tinggi dibanding metode gravimetri. 3,5-DNS (3,5Dinitrosalisilat acid) paling sering digunakan sebagai pereaksi gula reduksi. Hidrolisis dengan asam dan pemanasan pada metode ini menyebabkan glukomanan terhidrolisis membentuk glukosa dan mannose. Glukosa bereaksi dengan DNS membentuk asam 3amino-5-nitrosalisilat yang mampu menyerap radiasi gelombang elektromagnetik pada panjang gelombang maksimum $550 \mathrm{~nm}$ (Adney \& Baker, 2008). Hubungan gula reduksi dengan absorbansi adalah semakin tinggi kadar gula reduksi yang terdapat dalam sampel, maka akan semakin banyak pula molekul asam 3amino-5-nitrosalisilat yang terbentuk, sehingga absorbansi sampel akan semakin tinggi. Rasio BM glukosa dan residu manna di glukomanan : BM glukosa dan mannan yang dihasilkan setelah hidrolisis digunakan sebagai faktor koreksi.

Hasil penelitian menunjukkan bahwa kadar yang dihasilkan berkorelasi positif dengan 
meningkatnya waktu hidrolisis (Gambar 1). Kadar glukomanan terus meningkat dan mencapai kadar glukomanan tertinggi yaitu sebesar $37,39 \%$ pada waktu hidrolisis 100 menit, sedangkan kadar terendah adalah $24,57 \%$ diperoleh pada penggunaan waktu hidrolisis 70 menit.

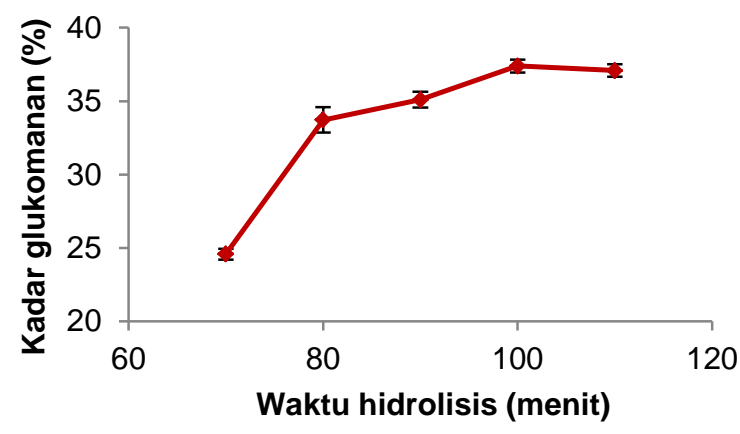

Gambar 1. Grafik hubungan waktu hidrolisis dengan kadar glukomanan.

Gambar 1 juga memperlihatkan bahwa kadar glukomanan biji durian mengalami peningkatan dari waktu hidrolisis 70 menit sampai 100 menit, hal ini menunjukkan bahwa semakin lama hidrolisis berlangsung maka kadar yang terdeteksi akan semakin meningkat. Hal ini dikarenakan semakin lama waktu hidrolisis maka semakin banyak pula jumlah glukomanan yang terhidrolisis menjadi glukosa dan mannan. Kadar glukomanan mulai menunjukkan sedikit penurunan pada waktu hidrolisis 110 menit yaitu sebesar 37,09\% karena waktu hidrolisis yang terlalu lama menyebabkan terjadinya karamelisasi yang menyebabkan rusaknya glukosa dan ditandai dengan terbentuknya warna kecoklatan pada sampel. Jika dibandingkan dengan penelitian terdahulu tentang waktu hidrolisis glukomanan dilaporkan bahwa waktu hidrolisis terbaik pada glukomanan dari tepung porang komersial yaitu selama 90 menit menghasilkan kadar glukomanan 93,21\% (Widjanarko \& Megawati, 2015).
Hasil analisis sidik ragam menunjukkan bahwa pengaruh waktu hidrolisis terhadap kadar glukomanan nilai signifikan 0,000 (sig. $<0,05$ ) atau waktu hidrolisis berpengaruh terhadap kadar glukomanan. Oleh karena itu, untuk menentukan waktu hidrolisis terbaik dapat dilakukan analisis lanjut dengan uji Duncan. Berdasarkan uji lanjut Duncan dengan taraf kepercayaan 95\% $(\alpha=0,05)$, diperoleh bahwa semua waktu 70, 80, 90 dan 100 menit berbeda nyata satu sama lain, sedangkan waktu hidrolisis 100 menit dan 110 menit berbeda tidak nyata. Dengan demikian waktu hidrolisis 100 menit dapat direkomendasikan untuk diaplikasikan dalam analisis kadar glukomanan dari tepung biji durian.

\section{Kadar Glukomanan Biji Durian pada Berbagai Suhu Hidrolisis}

Hasil yang diperoleh menunjukkan bahwa kadar tertinggi glukomnan adalah 39,60 \% pada perlakuan suhu hidrolisis $100^{\circ} \mathrm{C}$, sedangkan rendemen terendah adalah 25,09 \% pada penggunaan suhu hidrolisis $70^{\circ} \mathrm{C}$ (Gambar 2).

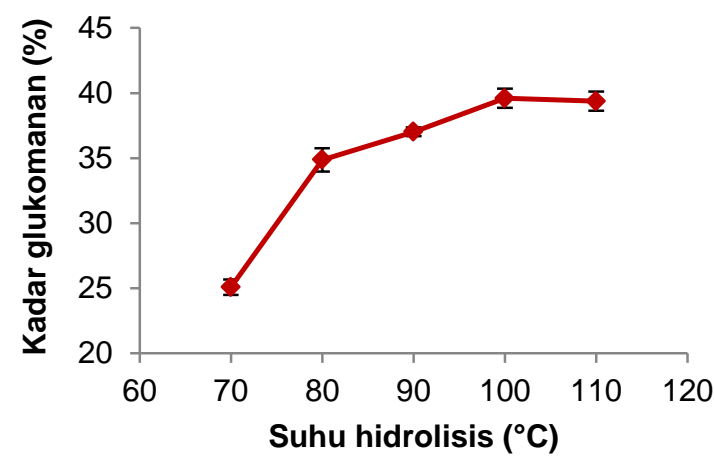

Gambar 2. Kurva hubungan waktu hidrolisis dengan kadar glukomanan.

Pada Gambar 2 menunjukkan peningkatan kadar glukomanan dari suhu $70^{\circ} \mathrm{C}$ hingga suhu $100^{\circ} \mathrm{C}$. Kadar tertinggi pada suhu $100^{\circ} \mathrm{C}$ sebesar $39,60 \%$ dan mulai menurun pada suhu $110^{\circ} \mathrm{C}$ menjadi $39,38 \%$. Suhu yang semakin tinggi mengakibatkan partikel-partikel bergerak 
semakin cepat dan mengakibatkan semakin banyak tumbukan antar pertikel yang membuat reaksi terjadi semakin cepat, namun pada saat mencapai suhu $110^{\circ} \mathrm{C}$ glukosa dalam sampel mulai rusak karena mengalami karamelisasi yang ditandai dengan terbentuknya warna kecoklatan dan endapan coklat. Dari penelitian terdahulu tentang suhu hidrolisis glukomanan dilaporkan bahwa suhu hidrolisis terbaik pada glukomanan dari tepung porang yaitu pada suhu $100^{\circ} \mathrm{C}$ menghasilkan kadar glukomanan $78,23 \%$ (Mustafa \& Widjanarko, 2015). Kadar glukomanan yang didapatkan dari biji durian lebih rendah dari kadar yang diperoleh pada literature, hal ini disebabkan karena kandungan PLA pada biji durian cukup kecil yaitu 4,28\% (Andini, 2014).

Hasil uji sidik ragam, pengaruh suhu hidrolisis terhadap kadar glukomanan menghasilkan nilai signifikan 0,000 (sig. < 0,05) atau suhu hidrolisis berpengaruh nyata terhadap kadar glukomanan. Hasil uji lanjut Duncan dengan taraf kepercayaan 95\% $\quad(\alpha=0,05)$ menunjukkan suhu hidrolisis $70,80,90$ dan $100^{\circ} \mathrm{C}$ berbeda nyata satu sama lain, sedangkan suhu hidrolisis $100^{\circ} \mathrm{C}$ dan $110^{\circ} \mathrm{C}$ berbeda tidak nyata. Dengan demikian, suhu hidrolisis $100^{\circ} \mathrm{C}$ dapat direkomendasikan untuk diaplikasikan dalam analisis kadar glukomanan dari tepung biji durian.

\section{KESIMPULAN}

Metode spektrofotometri untuk analisis kadar glukomanan akan menghasilkan ketelitian maksimal pada penggunaan suhu $100^{\circ} \mathrm{C}$ selama 100 menit. Kadar glukomanan yang diperoleh pada pada kombinasi suhu dan waktu hidrolisis tersebut adalah $39,60 \%$. Hasil analisis spektrofotometer FTIR menunjukkan bahwa terdapat beberapa pita serapan gugus fungsi penciri dari glukomanan, utamanya gugus $\mathrm{C}-\mathrm{O}-$ C (ikatan glikosidik) pada bilangan gelombang $1020,34 \mathrm{~cm}^{-1}$.

\section{DAFTAR PUSTAKA}

Adney, B., \& Baker, J. (2008). Measurement of Cellulose Activites-Laboratory Analytical Procedur (LAP). National Renewable Energy Laboratory, Colorado.

Aida, S., \& Laelia, A. (2011). Pemanfaatan Tepung Biji Durian Menjadi Glukosa Cair Melalui Proses Hidrolisa dengan Menggunakan Enzim a-Amilase [Monograph]. Universitas Diponegoro, Semarang.

Andini, C. (2014). Pengaruh Suhu dan Lama Maserasi Terhadap Rendemen dan Karakteristik Fungsional Teknik Ekstrak Kasar Polisakarida Larit Air Tepung Biji Durian. [Skripsi]. Jurusan Tekniligi Hasil Pertanian Fakultas Teknologi Pertanian Universitas Jember, Jember.

Anindita, F., Bahri, S., \& Hardi, J. (2016). Ekstraksi dan Karakterisasi Glukomanan dari Tepung Biji Salak (Salacca edulis Reinw.). KOVALEN, 2(2).

https://doi.org/10.22487/j24775398.201 6.v2.i2.6720

Chairul, C., \& Sofnie, M. (2006). ISOLASI Glukomanan Dari Dua Jenis Araceae: Talas \{Colocasia esculenta (L.) Schott\} Dan Iles-iles (Amorphophallus campanulatus Blumei). Berita Biologi, 8(3).

https://doi.org/10.14203/beritabiologi.v8i 3.793

Chao-bo, X., Shan-jun, G., Guo-rong, L., \& Qunchao, Z. (1999). Preparation of Konjac Glucomannan and Acrylamide Grafted Konjac Glucomannan. Wuhan University Journal of Natural Sciences, 4(4): 459-462. https://doi.org/10.1007/BF02832282

Fadilah, Distanatina, S., Prihani, H., \& Wulan. (2009). Koefisien Transfer Massa Volumetris (KEA) pada Ekstraksi Glukomanan dari Umbi lles-iles. 
Prosiding Simposium Nasoinal RAPI VIII. Simposium Nasoinal RAPI VIII, Surakarta.

Fatmawati, S., Bekti, N., \& Dewi, K. (2017). Ekstraksi Berbantu Ultrasonik dan Penetapan Kadar Glukomanan dalam Umbi Porang (Amorphophallus oncophyllus Prain ex Hook.f.). Media Farmasi Indonesia, 11(2): 1075-1083.

Hargono, K. (2008). Proses Pengolahan lles-iles (Amorphophallus sp.) Menjadi Glukomannan Sebagai Gelling Agent Pengganti Boraks. Momentum, 8(2): 38-41.

Kementan. (2016). Agrucultural Statistic. Kementrian Pertanian Republik Indonesia, Jakarta.

Mustafa, S., \& Widjanarko, S. B. (2015). Pengecilan Ukuran Metode Ball Mill Dan Pemurnian Kimia Terhadap Kemurnian Tepung Porang (Amorphophallus muelleri Blume). Jurnal Pangan Dan Agroindustri, https://jpa.ub.ac.id/index.php/jpa/article/ view/174

Nguyen, T. A., Do, T. T., Nguyen, T. D., Pham, L. D., \& Nguyen, V. D. (2010). Isolation and characteristics of polysaccharide from Amorphophallus corrugatus in Vietnam. Carbohydrate Polymers, 84(1): 64-68.

https://doi.org/10.1016/j.carbpol.2010.10 .074

Nurjannah, Z. (2010). Kajian Proses Pemurnian Tepung Glukomanan Dari Umbi lles-iles Kuning dengan Menggunakan Enzim aAmilase. [Skripsi]. Institut Pertanian Bogor, Bogor.

Prabowo, A. Y., Estiasih, T., \& Purwantiningrum, I. (2014). Umbi Gembili (Dioscorea esculenta L.) Sebagai Bahan Pangan Mengandung Senyawa Bioaktif: Kajian Pustaka. Jurnal Pangan Dan Agroindustri, 2(3): 129-135.

Retnowati, D. S., \& Kumoro, A. C. (2012). Mannan Precipitation from Aloe Vera Leaf Pulp Juice Using Methanol and Isopropyl Alcohol as Anti-Solvent: Experimental and Empirical Modelling
Approach. Reaktor, 14(1): 46-50. https://doi.org/10.14710/reaktor.14.1.46-50

Setiawati, E., Bahri, S., \& Razak, Abd. R. (2017). Ekstraksi Glukomanan Dari Umbi Porang (Amorphophallus paeniifolius (Dennst.) Nicolson). KOVALEN, 3(3). https://doi.org/10.22487/j24775398.201 7.v3.i3.9332

Singh, R. B., \& Shelley, N. (2007). Polysaccharide Structure of Degraded Glucomannan from Abrus precatorius Linn. Seeds. Journal of Environmental Biology, 28(2): 461-464.

Syaefullah, M. (1990). Studi Karakteristik Glukomanan dari Sumber "Indegenous" lles-iles (Amorphopallus oncophyllus) dengan Variasi Proses Pengeringan dan Dosis Perendaman. [Tesis]. Institut Pertanian Bogor, Bogor.

Wahyono. (2009). Karakteristik Edible Film Berbahan Dasar Kulit dan Pati Biji Durian (Durio sp) untuk Pengemasan Buah Strawberry [Skripsi]. Fakultas Keguruan dan IImu Pendidikan Universitas Muhammadiyah Surakarta, Surakarta.

Widjanarko, S. B., Nugroho, A., \& Estiasih, T. (2011). Functional Interaction Components of Protein Isolates And Glucomannan in Food Bars by FTIR and SEM Studies. J. Food Sci. 5(1): 12 - 21. https://doi.org/10.14303/AJFST.2014.008

Widjanarko, Simon Bambang, \& Megawati, J. (2015). Analisis Metode Kolorimetri dan Gravimetri Pengukuran Kadar Glukomanan pada Konjak (Amorphophallus konjac). Jurnal Pangan Dan Agroindustri, 3(4). https://jpa.ub.ac.id/index.php/jpa/article/ view/283

Yf, H., M, Z., Cx, F., Zh, C., \& Gy, C. (2004). Structural Characterization of a 2-OAcetylglucomannan from Dendrobium officinale stem. Carbohidrate Res, (339): 2219-2224. https://doi.org/10.1016/j.carres.2004.05.034 